\title{
Scoping Review: SGLT-2 Inhibitor Efektif dalam Menurunkan Albuminuria pada Pasien Diabetes Melitus Tipe 2
}

\author{
Virna Wulandari, ${ }^{1}$ Rika Nilapsari, ${ }^{2}$ Siti Annisa Devi $\mathbf{T}^{3}$ \\ ${ }^{1}$ Faculty of Medicine University Islam Bandung \\ ${ }^{23}$ Department of Clinical Pathology, University of Islam Bandung \\ 3Departement of Biochemistry, Nutrition and Biomolecular University of Islam Bandung
}

\begin{abstract}
Abstrak
Diabetes melitus (DM) merupakan penyakit tidak menular dengan insidensi terus meningkat setiap tahunnya. Salah satu komplikasi DM tersering adalah nefropati diabetik yang ditandai dengan albuminuria. Sodium glucose co-transporter (SGLT-2) inhibitor merupakan golongan obat antidiabetik yang bersifat insulin independen dan diharapkan menurunkan kejadian kerusakan fungsi ginjal. Kurangnya penelitian dan informasi obat golongan ini di Indonesia menyebabkan peneliti melakukan penelitian dengan tujuan mengetahui efektivitas pemberian obat golongan SGLT-2 inhibitor pada pasien DM tipe 2 terhadap penurunan kejadian albuminuria. Metode yang digunakan dalam penelitian ini adalah scoping review, dengan bahan penelitian artikel dari jurnal internasional yang memenuhi kriteria inklusi dan eksklusi. Artikel ini kemudian diseleksi menggunakan diagram PRISMA dengan mempertimbangkan Population (DM tipe 2), Intervention (pemberian SGLT-2 inhibitor), Comparison (plasebo atau anti diabetik lain), Outcome (penurunan albuminuria), Study (RCT dan Cohort retrospective). Didapatkan dari 13 artikel bahwa obat SGLT-2 inhibitor yang digunakan bervariasi yaitu canagliflozon (6), empagliflozin (3), dapagliflozin (2), ertugliflozin (2), dan yang tersering digunakan adalah canagliflozin ditemukan pada 6 artikel (50\%). Golongan obat SGLT-2 inhibitor memiliki kecenderungan yang sama, dapat ditoleransi dengan baik dan efektif dalam menurunkan kejadian albuminuria melalui mekanisme perubahan hemodinamik ginjal, dengan urin albumin-kreatinin rasio (UACR) sebagai parameter.
\end{abstract}

Kata kunci: Albuminuria, DM tipe 2, SGLT-2 inhibitor

\section{Scoping Review: SGLT-2 Inhibitors Effective to Reduce Albuminuria in Type 2 Diabetes Mellitus}

\begin{abstract}
Diabetes mellitus (DM) is a non-communicable disease with an increasing incidence every year. One of the most common complications of DM is diabetic nephropathy which is characterized by albuminuria. Sodium-glucose cotransporter (SGLT-2) Inhibitors is a class of anti-diabetic drugs that are insulin-independent and expected to reduce the incidence of impaired kidney function. The aim of this study was to ensure the effectiveness of SGLT-2 inhibitor drug administration in type $2 \mathrm{DM}$ patients to reduce the incidence of albuminuria. The method used is scoping review, with research articles from international journals sorted by the inclusion and exclusion criteria. These articles was selected using the PRISMA diagram by considering Population (DM type 2), Intervention (administration of SGLT2 inhibitors), Comparison (placebo or other anti-diabetic), Outcome (decreased albuminuria), Study (RCT and retrospective cohort). It was obtained from 13 articles that the SGLT-2 inhibitor drugs used varied, canagliflozon (6), empagliflozin (3), dapagliflozin (2), ertugliflozin (2), and the most commonly used was Canagliflozin found in 6 articles (50\%). The SGLT-2 inhibitor class of drugs has the same tendency, well-tolerated, and effective in reducing the incidence of albuminuria through the mechanism of renal hemodynamic changes, with urine albuminto-creatinine ratio (UACR) as a parameter.
\end{abstract}

Keywords: Albuminuria, SGLT-2 inhibitor, type 2 DM

Received: 8 ...; Revised: ...; Accepted: ...; Published: ...

Koresponden: Virna Wulandari. Faculty of Medicine University of Islam Bandung, Street Taman Sari no.22, Bandung, Province of West Java, Phone: +6281222402658, E-mail: virnawlndr@gmail.com 


\section{Pendahuluan}

Diabetes Melitus (DM) merupakan penyakit tidak menular dengan angka kejadian yang terus meningkat setiap tahunnya di seluruh dunia. Jumlah kasus DM di Indonesia dari 8,4 juta pada tahun 2000 menjadi 21,3 juta pada tahun $2030 .{ }^{1}$ ketika penyakit diabetes tidak dikelola dengan baik dapat menyebabkan komplikasi, sehingga akan menjadi beban ekonomi yang besar pada layanan sistem kesehatan dan ekonomi global. ${ }^{1}$ Penyebab penyakit Ginjal kronis endstage renal disease (ESRD) terbesar adalah nefropati diabetik (52\%) yang dapat dideteksi dini dengan kadar albuminuria. ${ }^{2}$ Kelainan fisiologis awal adalah hiperfiltrasi glomerulus terkait dengan hipertensi intraglomerular dengan timbulnya mikroalbuminuria. ${ }^{3}$ Setelah terdapat tanda nefropati (makroalbuminuria) terbentuk, fungsi ginjal turun pada tingkat yang signifikan tetapi dapat berubah. Gejala klinis diawali dengan ada adanya kadar albuminuria yang konsisten. ${ }^{3}$ Sodium-glucose cotransporter-2 (SGLT2) merupakan transporter protein yang diekspresikan dalam tubulus proksimal dari ginjal. Transporter tersebut menjadi target ideal dalam pengobatan diabetes karena 90\% berkontribusi dalam reabsorbsi glukosa. ${ }^{4}$

Kebutuhan pengetahuan mengenai perkembangan pengobatan sangat dibutuhkan. Sodium glucose cotransporter type 2 (SGLT2) inhibitors merupakan kelas baru anti-diabetik agen sebagai pilihan pengobatan untuk pasien diabetes tipe 2 dengan organ target ginjal. Mekanisme kerja SGLT-2 inhibitor adalah insulin independen, sehingga kerja obat tidak bergantung pada sel beta pankreas dan resistensi insulin. ${ }^{5}$ Blokade transporter SGLT-2 menghambat reabsorpsi natrium dan glukosa di PCT. Akibatnya, glukosa dan natrium meningkat di tubulus distal dan aparatus juxtaglomerular, sehingga terjadi peningkatan perfusi glomerulus. Hal ini menyebabkan sinyal umpan balik yang menyebabkan vasokonstriksi arteriol aferen dan terjadi penurunan akut perfusi dan tekanan glomerulus, serta penurunan volume plasma ekstraseluler dan tekanan darah. ${ }^{6}$

Tujuan penelitian ini adalah untuk mengetahui efektivitas dan jenis obat SGLT-2 inhibitor untuk mencegah kejadian albuminuria sehinga dapat dijadikan pertimbangan aplikasi pengobatan pasien DM tipe 2.

\section{Metode}

Penelitian mengenai efektivitas pemberian obat golongan SGLT-2 inhibitor pada pasien DM tipe 2 terhadap penurunan kejadian albuminuria dilakukan dengan metode scoping review. Prosedur penyusunan protokol dengan menggunakan metode PRISMA (preferred reporting items for systematic review and meta-analyses). Pencarian Data, dengan menggunakan Database Pubmed, ScienceDirect, SpringerLink, Proquest, Ebsco. Kata kunci yang digunakan adalah SGLT2 inhibitors, sodium glucose co-transporter 2, AND albuminuria. Skrining Data, merupakan penyaringan atau pemilihan data dengan memilih topik atau judul, abstrak, dan kata kunci yang sesuai dengan kriteria inklusi (artikel dari tahun
2010 - 2020, jenis artikel randomized controlled trials, artikel dapat diakses penuh, artikel berbahasa inggris) dan kriteria eksklusi (artikel yang tidak sesuai Population, Intervention, Comparison, Outcome, Study), membuang data atau artikel penelitian yang duplikasi. Penilaian Kualitas (Kelayakan) dipilih berdasar atas kesesuaian dengan kriteria PICOS (Population: penderita DM tipe 2; Intervention: pemberian obat SGLT-2 inhibitor; Comparison: pemberian plasebo atau obat anti diabetes lain; Outcome : penurunan kejadian albuminuria; Study : $R C T$ and Retrospective observational study).

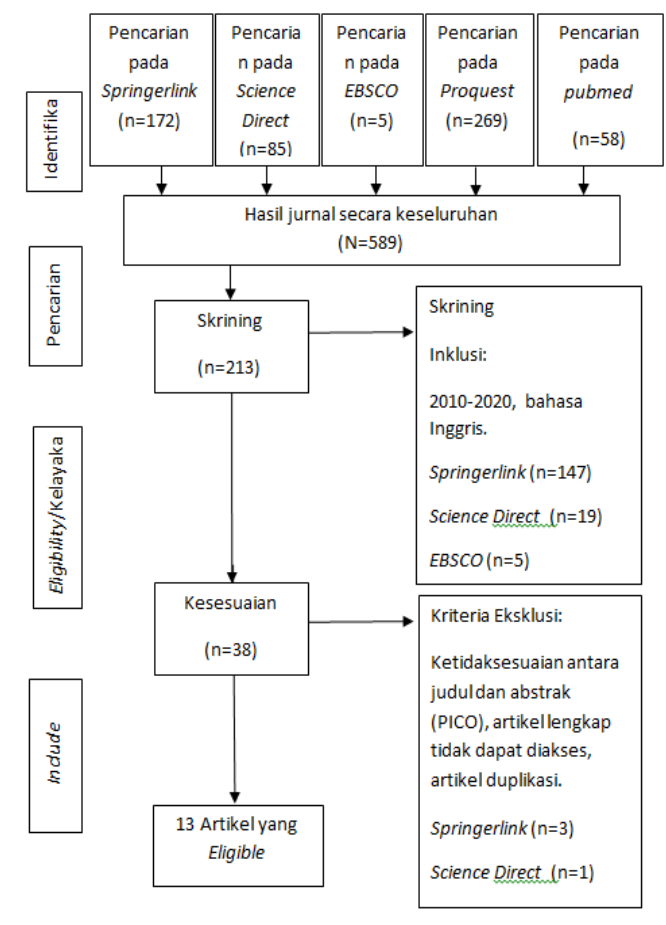

Gambar 1. Diagram prisma

\section{Hasil}

Hasil penelitian ini adalah sebagai berikut :

Berdasarkan Tabel 4.1 Penelitian banyak dilakukan pada rentang tahun 2016 hingga 2020, dengan lokasi penelitian tersebar di seluruh dunia. Pusat penelitian terbanyak dilakukan di negara Amerika Serikat dan Eropa yaitu Belgia, Kanada, Kolombia, Perancis, Jerman, Hungaria, diikuti Negara Asia India, Jepang, Korea, Malaysia, taiwan dan beberapa negara lainnya. Obat SGLT-2 inhibitor yang digunakan pada penelitian-penelitian tersebut bervariasi yaitu Canagliflozon (6), Empagliflozin (3), Dapagliflozin (2), ertugliflozin (2), dan yang tersering digunakan adalah Canagliflozin ditemukan pada 6 artikel (50\%). Metode penelitian hampir semua menggunakan control trial, hanya satu yang menggunakan retrospective observational study. 


\begin{tabular}{|c|c|c|c|c|c|c|}
\hline Judul/peneliti & Tujuan & $\begin{array}{l}\text { Desain } \\
\text { Penelitian }\end{array}$ & Intervensi & $\begin{array}{c}\text { Metode } \\
\text { pengukuran }\end{array}$ & Teknik Analisis & Hasil \\
\hline $\begin{array}{l}\text { Albuminuria-lowering } \\
\text { effect of dapagliflozin } \\
\text { alone and in } \\
\text { combination with } \\
\text { saxagliptin and effect of } \\
\text { dapagliflozin } \\
\text { and saxagliptin on } \\
\text { glycaemic control in } \\
\text { patients with } \\
\text { type } 2 \text { diabetes and } \\
\text { chronic kidney disease } \\
\text { (DELIGHT): } \\
\text { a randomised, double- } \\
\text { blind, placebo-controlled } \\
\text { trial } 2019 \\
\text { Australia CanadaJapan, } \\
\text { South Korea, Mexico, }\end{array}$ & $\begin{array}{l}\text { menilai efek penurunar } \\
\text { albuminuria dari } \\
\text { SGLT-2 Inhibitor } \\
\text { dapagliflozin dengan } \\
\text { dan tanpa saxagliptin, } \\
\text { dan efek dapagliflozin- } \\
\text { saxagliptin pada } \\
\text { kontrol glikemik pada } \\
\text { pasien dengan diabetes } \\
\text { tipe } 2 \text { dan penyakit } \\
\text { ginjal kronis sedang } \\
\text { hingga berat. }\end{array}$ & $\begin{array}{l}\text { ndouble-blind, placebo- } \\
\text { controlled trial } \\
461\end{array}$ & $\begin{array}{l}\text { Pemberian secara } \\
\text { acak (1: 1: 1; melalui } \\
\text { sistem respon } \\
\text { suara-web interaktif) } \\
\text { untuk menerima } \\
\text { dapagliflozin (10 mg) } \\
\text { saja, dapagliflozin } \\
\text { (10 mg) dan } \\
\text { saxagliptin ( } 2 \cdot 5 \\
\text { mg), atau plasebo } \\
\text { sekali sehari selama } \\
24 \text { minggu }\end{array}$ & $\begin{array}{l}\text { (urine albumin-to- } \\
\text { creatinine ratio [UACR } \\
30-3500 \mathrm{mg} / \mathrm{g} \text { ) } \\
\text { ) }\end{array}$ & $\begin{array}{l}\text { inferensi statistik } \\
\text { ddari keunggulan } \\
\text { dibuat pada } \leq \mathrm{0} \cdot 1 \\
\text { O25 untuk setiap } \\
\text { perbandingan } \\
\text { yang telah } \\
\text { ditentukan } \\
\text { sebelumnya; dan } \\
\text { untuk intervensi } \\
\text { saxagliptin- } \\
\text { dapagliflozin, } \\
\text { p } \leq \text { O } \cdot \text { O25 } \\
\text { diperlukan untuk } \\
\text { kedua titik akhir } \\
\text { co-primer untuk } \\
\text { menentukan } \\
\text { signifikansi }\end{array}$ & $\begin{array}{l}\text { Pemberian obat } \\
\text { Dapagliflozin } \\
\text { pada penderita } \\
\text { DM dengan } \\
\text { penyakit ginjal } \\
\text { kronis mengurangi } \\
\text { albuminuria dan } \\
\text { HbA1c, dan efek } \\
\text { ini lebih kuat } \\
\text { bila dapagliflozin } \\
\text { dikombinasi dengan } \\
\text { saxagliptin. }\end{array}$ \\
\hline
\end{tabular}

South Africa, Spain,

Taiwan, and the USA

Canagliflozin and

melaporkan efek Randomized,Multicenter,canagliflozin atau

Cardiovascular and Renal pengobatan dengan Double-Blind, Parallel, plasebo dengan

Events in Type 2 Diabetes canagliflozin pada hasil Placebo-Controlled Study rasio 1: 1: 1 untuk 2017

kardiovaskular, ginjal, $10.142 \quad$ menerima

667 centers in 30 countriesdan keamanan

$300 \mathrm{mg}$,

canagliflozin atau

$100 \mathrm{mg}$, atau plasebo
Median albumin-tocreatinine ratio menggunakan model regresi Cox, dengan stratifikasi

menurut

percobaan dan

riwayat penyakit

kardiovaskula

untuk semua

kelompok

canagliflozin yang

\begin{tabular}{|c|c|c|}
\hline $\begin{array}{l}\text { Canagliflozin and } \\
\text { Renal Outcomes in } \\
\text { Type } 2 \text { Diabetes and } \\
\text { Nephropathy } \\
2019 \\
667 \text { centres in } 30 \text { countries }\end{array}$ & $\begin{array}{l}\text { melaporkan hasil } \\
\text { analisis eksplorasi } \\
\text { yang telah ditentukan } \\
\text { sebelumnya dari } \\
\text { efek jangka panjang } \\
\text { scanagliflozin yang } \\
\text { bermanfaat pada ginjal }\end{array}$ & $\begin{array}{l}\text { Randomized, } \\
\text { Multicenter, double- } \\
\text { Blind, Parallel,Placeboc } \\
\text { Controlled Study } \\
4.401 \\
1\end{array}$ \\
\hline $\begin{array}{l}\text { Canagliflozin and renal } \\
\text { outcomes in type } 2 \\
\text { diabetes: } \\
\text { results from the CANVAS } \\
\text { Program randomised } \\
\text { clinical trials } \\
2018 \\
354 \text { centers of } 57 \text { countries }\end{array}$ & $\begin{array}{l}\text { Mengetahui efek } \\
\text { SGLT-2 inhibitor dapat } \\
\text { meningkatkan fungsi } \\
\text { ginjal pada pasien } \\
\text { dengan diabetes tipe } 2\end{array}$ & $\begin{array}{l}\text { Randomized, } \\
\text { t Multicenter, double- } \\
\text { Blind, Parallel,Placeb } \\
\text { Controlled Study } \\
10.142\end{array}$ \\
\hline
\end{tabular}

Diberikan secara albuminuria (ratio acak (1: 1) untuk of albumin [mg] to canagliflozin (100 creatinine [g], >300 mg setiap hari) atau to 5000 )

plasebo dengan

canagliflozin

uptitrasi opsional

(300 mg setiap hari)

atau plasebo

Pemberian

canagliflozin 10omg (Rasio Albumin

or placebo

Kreatinin Urine
$[\mathrm{UACR}] 30$ hingga 300
$[\mathrm{mg} / \mathrm{g}]$ )

Diamati untuk Pada pasien DM tipe

hasil primer 2 dengan penyakit

$(\mathrm{P}<0,01)$ dan ginjal, pemberian

gabungan Canagliflozin

penyakit ginjal menurunkan risiko

stadium akhir gagal ginjal dan

atau kematian kardiovaskular

akibat ginjal atau ditandai dengan

kardiovaskular (Ppenurunan kejadian

$<0,025) \quad$ albuminuria

Untuk hasil Pemberian Cana-

kategoris, HR gliflozin menurunkan

dan $95 \%$ CI risiko penurunan

diperkirakan fungsi ginjal, menu-

yang ingin albuminuria dan

diobati dengan penurunan eGFR

menggunakan

model Cox dari

hasil gabungan

ginjal sebagai

kovariat yang

bervariasi waktu

Canagliflozin Slows

Tujuan dari penelitian randomized, double-

glimepiride oral

sekali sehari

(ditingkatkan

mixed-effects

model for

repeated

measures

(MMRM)

$8 \mathrm{mg} /$ hari atau

canagliflozin1oomg

/hari, canagli flozin

30omg /hari 1: 1:

1 rasio
Canagliflozin dosis 100 dan $300 \mathrm{mg}$ memberikan efek menurunkan progresifitas komplikasi ginjal, ditandai dengan menurunnya

albuminuria dan memperlambat laj penurunan eGFR selama 2 tahun.

Keterbatasan

:Setelah 2 tahun

tidak dilihat lagi 
Effect of Canagliflozin on Untuk menentukan Renal and Cardiovascular efek canagliflozin Outcomes across Different pada hasil ginjal,

Levels of Albuminuria: $\quad$ kardiovaskular, dan Data from the CANVAS keamanan pada orang Program dengan DMT2 sesuai

$2019 \quad$ dengan tingkat dasar

667 centers across $30 \quad$ albuminuria

countries

\author{
doubleblind, placebo- $\quad$ Canagliflozin atau \\ controlled randomized placebo \\ trials \\ 10.142
}

albuminuria (UACR menggunakan uji Pada populasi DM $.300 \mathrm{mg} / \mathrm{g}$ ) at baseline chi-kuadrat dan tipe 2, pembeANOVA untuk rian Canagliflozin variabel kategori meningkatkan fungsi dan kontinu ginjal. pada pasien normoalbuminuria

Canagliflozin memberikan efek protektif, dan sangat bermanfaat pada penderita dengan albuminuria yang sudah berat

\begin{tabular}{|c|c|c|c|}
\hline $\begin{array}{l}\text { Effects of ertugliflozin on } \\
\text { renal function over } 104 \\
\text { weeks of treatment: a } \\
\text { post hoc analysis of two } \\
\text { randomised controlled } \\
\text { trials } \\
2020\end{array}$ & $\begin{array}{l}\text { mengevaluasi efek } \\
\text { ertugliflozin, (SGLT2), } \\
\text { pada eGFR dan } \\
\text { albuminuria (rasio } \\
\text { albumin / kreatinin } \\
\text { urin [UACR]) vs } \\
\text { glimepiride atau } \\
\text { plasebo / glimepiride } \\
\text { (non-ertugliflozin) } \\
\text { selama 104 minggu }\end{array}$ & $\begin{array}{l}\text { Rondomized controlled } \\
1936\end{array}$ & $\begin{array}{l}\text { Pemberian } \\
\text { ertugliflozin vs } \\
\text { glimepirid atau } \\
\text { placebo }\end{array}$ \\
\hline
\end{tabular}

Pasien dengan menggunakan Pemberian albuminuria UACR model analisis Ertigliflozin awal $\geq 3,39 \mathrm{mg} / \mathrm{mmol}$ data longitudinal. mengurangi dan tanpa albuminuria Model kovariat albuminuria (UACR $<3.39 \mathrm{mg} /$ dasar (HbA1c, (UACR) pada $\mathrm{mmol}$ ) TD sistolik dan durasi pemberian eGFR untuk diatas 6 minggu, analisis eGFR, dan pada penderita dan HbA1c, dengan baseline TD sistolik dan mikroalbuminuria UACR untuk analisis UACR)


mengetahui efek Disease in Type 2 Diabetesjangka panjang dari

2016 empagliflozin pada

590 center di 42 negara ginjal

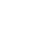

\section{Randomized trials}

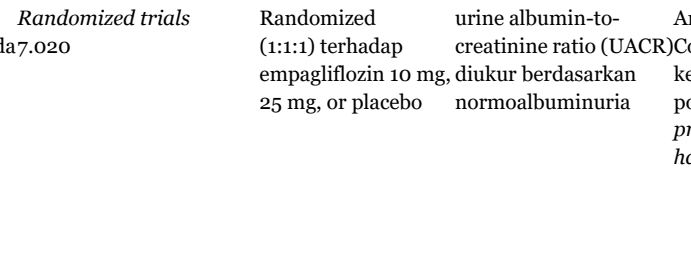

\section{Analisis regresi Pada pasien Asia} Cox untuk dari EMPA-REG keseluruhan OUTCOME®, populasi. Cox pemberian proportional- empagliflozin dapat hazards model meningkatkan fungsi ginjal penderita DM tipe 2, ditandai dengan perlambatan pada eGFR serta

menurunkan albuminuria

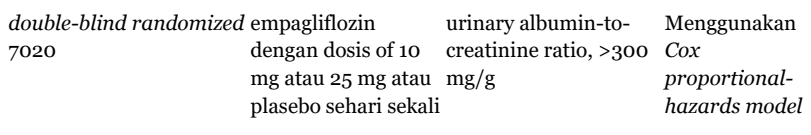
Pemberian empagliflozin pada penderita DM tipe

2 dengan resiko kardiovaskuler, menurunkan progresivitas komplikasi ginjal (ditandai dengan lebih rendah kejadian progresifitas keakroalbuminuria),

Impact of sodiumglucose cotransporter 2 inhibitors on renal function in participants membandingkan efek $S G L T 2$ inhibito pada fungsi ginjal pada peserta dengan With type 2 diabetes and penyakit ginjal chronic kidney disease kronis (CKD) yang

With normoalbuminuria diklasifikasikan

$2020 \quad$ berdasarkan derajat

Asosiasi Diabetes Dokter albuminuria.

Jepang University

Hospital Medical

Information Network

\section{Retrospective} Observational study
Urinary albuminto-creatinine ratio (UACR) , 30mg/g
Data dinyatakan SGLT-2 inhibitor sebagai mean \pm memiliki efek standar deviasi yang lebih atau median. menguntungkan Perbedaan pada peserta DM tipe karakteristik 2 dan CKD dengan dasar dan albuminuria yang perubahan di normal, SGLT-2 antara ketiga inhibitor memiliki kelompok efek renoprotektif dibandingkan tergantung dari dengan analisis derajat albuminuria varian satu arah diikuti dengan uji post hoc bonferroni atau uji chi square. Nilai $\mathrm{P}<\mathrm{0}, 05$ 


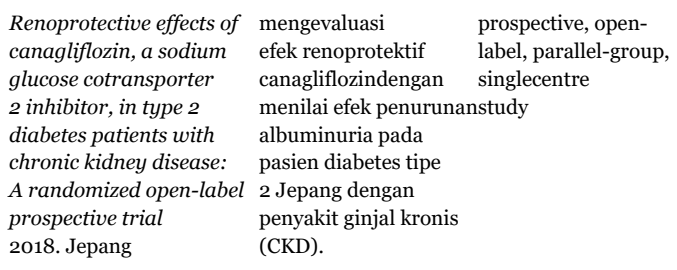

$\begin{array}{lll}\begin{array}{l}\text { The albuminuria } \\ \text { lowering response to }\end{array} & \begin{array}{l}\text { Penelitian ini untuk } \\ \text { menilai apakah } \\ \text { dapagliflozin is variable } \\ \text { efek penurunan }\end{array} & \begin{array}{l}\text { double-blind, } \\ \text { randomized, placebo } \\ \text { and reproducible between }\end{array} \\ \begin{array}{ll}\text { albuminuria bervariasi } \\ \text { individual patients. }\end{array} & \begin{array}{l}\text { antara pasien, dan } \\ \text { ant }\end{array} \\ \text { 2017 } & \text { apakah variabilitas } \\ \text { Belanda } & \text { respon ini dapat }\end{array}$

Secara acak Albuminuria: urinary Data dinyatakan Canagliflozin menerima albumin-to-creatinine sebagai mean memberikan efek canagliflozin oral $(\mathrm{Cr})$ ratio (UACR) \pm standar perlambatan (100 mg/ hari) atau $30-2000 \mathrm{mg} / \mathrm{g}$ deviasi atau penyakit ginjal, perawatan biasa median (kisaran menurunkan selama 52 minggu interkuartil) albuminuria, dan yang sesuai. menjadi penanda Variabel kontinu tubulointerstisial dibandingkan pada pasien diabetes menggunakan uji dengan CKD T Student atau uji Mann-Whitney U

dapagliflozin $10 \mathrm{mg} /$ albumin:creatinine Transformasi Dapagliflozin hari atau ratio (UACR) Fisher's z secara signifikan placebo $\quad \geq 100 \mathrm{mg} / \mathrm{g}$ and $<3500$ 'dilakukan untuk dapat mengurangi $\mathrm{mg} / \mathrm{g} \quad$ menghitung CI albuminuria saat 95\% dari korelasi.diberikan bersamaan dengan ACE atau $\mathrm{ARB}$

The effect of sodium glucose cotransporter 2 inhibition with empagliflozin on microalbuminuria and macroalbuminuria in patients with type 2 diabetes

2016

Berlin

\section{Diskusi}

Seperti telah dibahas dalam hasil, jenis obat golongan SGLT2 inhibitor yang sering digunakan adalah Canagliflozin, Dapagliflozin, Empagliflozin dan Ertugliflozin. Terdapat beberapa obat yaitu Lusegliflozin, Tofogliflozin, Sotagliflozin masih dalam tahap pra-registrasi dan tahap uji klinis sebelum di distribusikan. ${ }^{5}$ Obat terbanyak yang digunakan pada 13 artikel adalah Canagliflozin yakni 50\% dari 13 penelitian yang ada, diikuti terbanyak kedua adalah empaglflozin dan kemudian Dapagliflozin dan ertugliflozin.

Canagliflozin lebih banyak ditemukan dalam penelitian di Amerika serikat dan Kanada karena 2 negara tersebut adalah pusat penelitian (Canagliflozin Cardiovascular Assessment Study Renal) CANVAS -R yaitu penelitian khusus obat Canagliflozin terhadap populasi DM dengan gangguan kardiovaskuler dan renal. ${ }^{7}$ Amerika juga sebagai negara pertama yang menerbitkan persetujuan obat tersebut pada maret tahun 2013. Selanjutnya negara eropa lainnya mengikuti pada akhir tahun 2013. Peluncuran obatobat lainnya seperti Dapagliflozin, Empagliflozin dan Ertugliflozin menyusul kemudian di tahun 2014 di Eropa dan Amerika serikat. ${ }^{8}$ Berbagai uji terhadap efektivitas dan keamanan obat SGLT2 inhibitor dilakukan melalui berbagai trials seperti CANVAS-R, EMPA reg trials, VERTIS trial, yang semuanya meneliti efektivitas dan keamanan obat pada penderita DM tipe 2 yang disertai gangguan ginjal, gangguan jantung, dilihat dengan parameter eGFR, albuminuria serta nilai Hba1C.

Efektivitas obat golongan SGLT2 inhibitor ini terhadap penderita DM tipe 2 dengan gangguan ginjal (nefropati diabetik) yang ditandai dengan adanya kadar albuminuria bervariasi tergantung stadium pada penyakit ginjalnya, jenis SGLT 2 inhibitor yang diberikan, kombinasi obat serta dosis yang diberikan. Canagliflozin menurunkan albuminuria dengan penurunan proporsional yang lebih besar dengan albuminuria yang meningkat sedang dan berat (heterogenitas $\mathrm{P}<0,001) .{ }^{6}$ Pada penelitian obat dapagliflozin, mampu menurunkan kadar albuminuria pada 38 sampel pasien yang memiliki riwayat CKD yaitu sebesar 36,2\% (95\% CI 22,9 menjadi 47,2; P $<$ o,o01). ${ }^{9}$ Empagliflozin terbukti dapat mengurangi risiko insiden atau memburuknya nefropati (rasio hazard [HR] o,64; interval confidence 95\% [CI] 0,49, $0,83),{ }^{10}$ Kelompok obat jenis ertugliflozin penurunan kejadian albuminuria paling banyak UACR (95\% CI) dibandingkan dengan kelompok non-ertugliflozin adalah $(-44.8,-9.8 ; \mathrm{p}<0.01){ }^{11}$

Sodium-glukosa co-transporter-2 inhibitor bekerja dengan menghambat SGLT-2 di PCT, untuk mencegah reabsorpsi glukosa dan memfasilitasi ekskresi glukosa dalam urin. Penurunan albuminuria memiliki mekanisme yang sebagian besar tidak bergantung pada glukosa melainkan pada melalui perubahan hemodinamik ginjal. ${ }^{6}$ Blokade transporter SGLT2 menghambat reabsorpsi natrium dan glukosa di PCT. Akibatnya, glukosa dan natrium meningkat di tubulus distal dan aparatus juxtaglomerular, sehingga terjadi peningkatan perfusi glomerulus. Hal ini menyebabkan sinyal umpan balik yang menyebabkan vasokonstriksi arteriol aferen dan terjadi penurunan akut perfusi dan tekanan glomerulus, serta penurunan volume plasma ekstraseluler dan tekanan darah. ${ }^{6}$ Selain itu, efek tersebut mengurangi sekresi peptida natriuretik atrium yang mungkin juga penting dalam mengurangi tekanan intraglomerular. Efek ini secara klinis dimanifestasikan sebagai penurunan albuminuria dan eGFR. Kesimpulannya SGLT2 inhibitor dapat mengubah hemodinamik ginjal dan 
mengurangi tekanan intraglomerular, yang diharapkan dapat meningkatkan fungsi ginjal jangka panjang. ${ }^{6}$

Pemberian obat golongan SGLT-2 inhibitor tidak ada peserta yang menunjukkan efek samping yang signifikan seperti gejala hipoglikemia, infeksi saluran kemih, infeksi genital atau amputasi anggota badan.6,10,12 Tidak ada risiko hipoglikemia, hiperkalemia, cedera gijal akut, keganasan atau tromboemboli vena. Keterbatasan penelitian ini adalah terdapat beberapa jurnal dengan prosedur yang kurang jelas pada beberapa penelitian sehingga kesulitan melihat keseragaman pada semua penelitian, sampel tidak homogen, ada beberapa penelitian yang disertai gangguan kardiovaskuler, penelitian tidak banyak dilakukan pada ras Asia terutama Indonesia. Saran peneliti Sebagai obat baru, perlu dilakukan kembali penelitian dengan prosedur yang jelas dan sampel yang homogen serta dilakukan penelitian pada populasi orang Asia sehingga bisa didapatkan data uji klinis dan distribusi obat SGLT2 inhibitor di asia terutama Indonesia.

\section{Kesimpulan}

Berdasarkan data yang diperoleh dari penelitian, jenis obat-obatan SGLT-2 yang sering digunakan untuk menurunkan kejadian albuminuria pada penderita DM tipe 2 adalah Canagliflozin, Dapagliflozin, Empagliflozin, dan Ertugliflozin dan obat-obatan tersebut terbukti efektif dalam menurunkan kejadian albuminuria pada penderita DM tipe 2 .

\section{Konflik kepentingan}

Penulis menyatakan tidak ada komflik kepentingan pada penelitian ini.

\section{Ucapan Terimakasih}

Penulis mengucapkan terima kasih kepada seluruh pihak yang telah membantu dalam penyusunan artikel ini.

\section{Referensi}

1. WHO. Global Report on Diabetes. Isbn. 2016;978:6-86. [diunduh 14 Oktober]. Tersedia dari:

licensing/.

http://www.who.int/about/

2. Kementerian Kesehatan RI. Cegah dan kendalikan dengan cerdik dan patuh. 2018:6-8. [diunduh 18 oktober 2019] tersedia dari : http://www.depkes. go.id/article/print/18030700007/cegah-dankendalikan-penyakit-ginjal-dengan-cerdik-danpatuh.html.

3. Nazar CMJ. Diabetic nephropathy; principles of diagnosisand treatmentofdiabetickidneydisease. $J$ nephropharmacology. 2014;3(1):15-20. [diunduh 27 Januari 2020]. tersedia di : http://www.ncbi. nlm.nih.gov/pubmed/28197454\%oAhttp:// www.pubmedcentral.nih.gov/articlerender. fcgi?artid=PMC5297588.
4. Kalra S. Sodium Glucose Co-Transporter-2 (SGLT2) Inhibitors: A Review of Their Basic and Clinical Pharmacology. Diabetes Ther. 2014;5(2):355-66.

5. Nauck MA. Update on developments with SGLT2 inhibitors in the management of type 2 diabetes. Drug Des Devel Ther. 2014;8:1335-51. [diunduh 11 oktober 2020] Tersedia dari : https://www. ncbi.nlm.nih.gov/pmc/articles/PMC4166348/

6. Takashima H, Yoshida Y, Nagura C, Furukawa T, Tei R, Maruyama T, et al. Renoprotective effects of canagliflozin, a sodium glucose cotransporter 2 inhibitor, in type 2 diabetes patients with chronic kidney disease: A randomized openlabel prospective trial. Diabetes Vasc Dis Res. 2018;15(5):469-72. [diunduh 16 november 2020]. tersedia di https://journals.sagepub.com/ doi/full/10.1177/1479164118782872

7. Perkovic V, Jardine MJ, Neal B, Bompoint S, Heerspink HJL, Charytan DM, et al. Canagliflozin and Renal Outcomes in Type 2 Diabetes and Nephropathy. N Engl J Med. 2019;380(24):2295306. [diunduh 16 november 2020]. tersedia di https://www.nejm.org/doi/full/10.1056/ nejmoa1811744

8. Wilding J, Fernando K, Milne N, Evans M, Ali A, Bain S, et al. SGLT2 Inhibitors in Type 2 Diabetes Management: Key Evidence and Implications for Clinical Practice. Diabetes Ther [Internet]. 2018;9(5):1757-73.Tersedia dari: https://doi. org/10.1007/s13300-018-0471-8

9. Petrykiv SI, Laverman GD, de Zeeuw D, Heerspink HJL. The albuminuria-lowering response to dapagliflozin is variable and reproducible among individual patients. Diabetes, Obes Metab. 2017;19(10):1363-70. [diunduh 16 november 2020]. Tersedia di https://pubmed.ncbi.nlm.nih. gov/28295959/

10. Pollock C, Stefánsson B, Reyner D, Rossing P, Sjöström CD, Wheeler DC, et al. Albuminurialowering effect of dapagliflozin alone and in combination with saxagliptin and effect of dapagliflozin and saxagliptin on glycaemic control in patients with type 2 diabetes and chronic kidney disease (DELIGHT): a randomised, double-blind, plac. Lancet Diabetes Endocrinol. 2019;7(6):42941. [diunduh 16 november 2020]. tersedia di https://pubmed.ncbi.nlm.nih.gov/30992195/

11. Cherney DZI, Heerspink HJL, Frederich R, Maldonado M, Liu J, Pong A, et al. Effects of ertugliflozin on renal function over 104 weeks of treatment: a post hoc analysis of two randomised controlled trials. Diabetologia. 2020;63(6):112840. [diunduh 18 november 2020]. tersedia di https://www.nejm.org/doi/full/10.1056/ nejmoa1611925

12. Kadowaki T, Nangaku M, Hantel S, Okamura T, von Eynatten M, Wanner C, et al. Empagliflozin and kidney outcomes in Asian patients with type 2 diabetes and established cardiovascular disease: Results from the EMPA-REG OUTCOME $₫$ trial. J Diabetes Investig. 2019;10(3):760-70. [diunduh 18 november 2020$]$. tersedia di https://pubmed. ncbi.nlm.nih.gov/30412655/ 
13. Perkovic V, de Zeeuw D, Mahaffey KW, Fulcher G, Erondu N, Shaw W, et al. Canagliflozin and renal outcomes in type 2 diabetes: results from the CANVAS Program randomised clinical trials. Lancet Diabetes Endocrinol [Internet]. 2018;6(9):691-704. [diunduh 18 november 2020]. tersedia di http://dx.doi.org/10.1016/ S2213-8587(18)30141-4

14. Wanner C, Inzucchi SE, Lachin JM, Fitchett D, von Eynatten M, Mattheus M, et al. Empagliflozin and Progression of Kidney Disease in Type 2 Diabetes. N Engl J Med. 2016;375(4):323-34. [diunduh 18 november 2020]. tersedia di https://www.nejm. org/doi/full/10.1056/NEJMoa1515920

15. Nakamura A, Miyoshi H, Kameda H, Yamashita $\mathrm{K}$, Kurihara $\mathrm{Y}$. Impact of sodium-glucose cotransporter 2 inhibitors on renal function in participants with type 2 diabetes and chronic kidney disease with normoalbuminuria. Diabetol Metab Syndr [Internet]. 2020;12(1):1-6. [diunduh 18 november 2020]. tersedia di https://doi. org/10.1186/s13098-020-0516-9

16. Heerspink HJL, Desai M, Jardine M, Balis D, Meininger G, Perkovic V. Canagliflozin slows progression of renal function decline independently of glycemic effects. J Am Soc Nephrol. 2017;28(1):368-75. [diunduh 18 november 2020]. tersedia di https://www. ncbi.nlm.nih.gov/pmc/articles/PMC7228910/ pdf/125_2020_Article_5133.pdf

17. Neal B, Perkovic V, Mahaffey KW, de Zeeuw D, Fulcher G, Erondu N, et al. Canagliflozin and Cardiovascular and Renal Events in Type 2 Diabetes. N Engl J Med. 2017;377(7):644-57. [diunduh 16 november 2020]. tersedia di https:// www.nejm.org/doi/full/10.1056/nejmoa1611925

18. Neuen BL, Ohkuma T, Neal B, Matthews DR, De Zeeuw D, Mahaffey KW, et al. Effect of canagliflozin on renal and cardiovascular outcomes across different levels of albuminuria: Data from the CANVAS program. J Am Soc Nephrol. 2019;30(11):2229-42. [diunduh 18 november 2020]. tersedia di https://pubmed. ncbi.nlm.nih.gov/31530577/

19. John P, Yadla M. Noninvasive method of differentiating diabetic nephropathy and nondiabetic renal disease using serum bone morphogenetic protein-7 and transforming growth factor-beta 1 levels in patients with type2 diabetes mellitus. Saudi J Kidney Dis Transpl. 2019;30(6):1300-1309. doi:10.4103/13192442.275474

20. Toth-Manikowski S, Atta MG. Diabetic kidney disease: Pathophysiology and therapeutic targets. J Diabetes Res. 2015;2015. doi:10.1155/2015/697010 [diunduh 26 november 2020]. tersedia di https://www.hindawi.com/ journals/jdr/2015/697010/

21. Lim AKH. Diabetic nephropathy - Complications and treatment. Int $\mathrm{J}$ Nephrol Renovasc Dis. 2014;7:361-381. doi:10.2147/IJNRD.S40172

22. Ley SH, Schulze MB, Hivert M-F, Meigs JB, Hu FB. Risk Factor for Type 2 Diabetes Melitus. Med clínica. 2015. 17;116(10):398-9. [monograph on the internet]. [diunduh 12 november 2019]. tersedia di : http://www.ncbi.nlm.nih.gov/ pubmed/11333683.

23. Care D, Suppl SS. Classification and diagnosis of diabetes: Standards of medical care in Diabetesd2018. Diabetes Care. 2018;41(January):S13-S27. doi:10.2337/ dc18-SoO2

24. Khairani. Hari Diabetes Sedunia Tahun 2018. Pus Data dan Inf Kementrian Kesehat RI. 2019:1-8. [diunduh 5 Desember 2019] Tersedia dari : https:// pusdatin.kemkes.go.id/resources/download/ pusdatin/profil- kesehatan-indonesia/Data-danInformasi_Profil-Kesehatan-Indonesia- 2017.pdf

25. Gripp KW, Ennis S, Napoli J. Exome Analysis in Clinical Practice: Expanding the Phenotype of Bartsocas-Papas Syndrome. Am J Med Genet Part A. 2013;161(5):1058-1063. doi:10.1002/ ajmg.a.35913. 